\title{
Accuracy of Boresight Equipment for the 25-Millimeter Gun of the Bradley Fighting Vehicle
}

\author{
Mike S. Perkins and Craig S. Wilkinson \\ Litton Systems, Inc.
}

\begin{abstract}
ARI Field Unit at Fort Benning, Georgia
Seward Smith, Chief
\end{abstract}

\author{
Training Research Laboratory \\ Jack H. Hiller, Director \\ U.S. ARMY RESEARCH INSTITUTE FOR THE BEHAVIORAL AND SOCIAL SCIENCES \\ 5001 Eisenhower Avenue, Alexandria, Virginia 22333-5600 \\ Office, Deputy Chief of Staff for Personnel \\ Department of the Army \\ May 1988
}

Approved for public release; distribution unlimited. 